Arch. Tierz., Dummerstorf 47 (2004) 1, 75-84

Agricultural University of Szczecin, Poland

PIOTR BARANOWSKI, WIESŁAWA KLATA and STANISŁAW BARANOW-

BARANOWSKI

\title{
Macroelements concentration in the osseous tissue of caudal vertebrae in domestic sheep lambs and of mandibular bone in roe deer bucks coming from the northern and the southern region of Western Pomerania in Poland
}

\begin{abstract}
The aim of the studies was to compare Na, K, Ca, Png and Mg concentrations in the blood serum of lambs coming from the northern and the southern region of Western Pomerania, as well as to compare the concentration of these elements in the osseous tissue of caudal vertebrae in sheep lambs and of mandible in roe deer bucks populating the areas of the same agrocenoses - cultivated fields and meadows. The studies were carried out in the same year on the blood serum and the osseous tissue of the 4th and 5th caudal vertebrae of 99days-old Polish Merino lambs ( \pm 2 days) of both sex and on the mandibular osseous tissue of 62 roe deer bucks (Capreolus capreolus) of an "ecological field population". Fifty lambs, with the average body weight of $7.26 \mathrm{~kg}$ \pm 1.49 , came from a fold in the coastal zone of the Western Pomeranian Province (53 $599^{\prime} \mathrm{N} ; 15^{\circ} 18^{\prime} \mathrm{E}$ ), and 49 lambs, with the average body weight of $7.64 \mathrm{~kg} \pm 1.87$, from an area far removed by approximately $130 \mathrm{~km}$ to the south $\left(53^{\circ} 25^{\prime} \mathrm{N} ; 14^{\circ} 81^{\prime} \mathrm{E}\right)$. The feeding of lamb dams was standardized. In the blood serum of lambs from the north, higher concentrations of $\mathrm{K}(\mathrm{P} \leq 0.05)$ and $\mathrm{Ca}, \mathrm{P}_{\mathrm{ng}}$ and $\mathrm{Mg}(\mathrm{P} \leq 0.01)$ were recorded, as well as a lower concentration of $\mathrm{Na}(\mathrm{P} \leq 0.05)$. The osseous tissue of caudal vertebrae of these lambs contained significantly less $\mathrm{Na}, \mathrm{Ca}, \mathrm{P}_{\mathrm{ng}}$ and $\mathrm{Mg}(\mathrm{P} \leq 0.01)$ and more $\mathrm{K}(\mathrm{P} \leq 0.01)$ compared to the lambs from the south. The age of bucks was not a source of variation for the content of examined macroelements in the osseous tissue of their mandibles. Higher concentration of $\mathrm{Ca}(\mathrm{P} \leq 0.01)$ was recorded in the mandibular osseous tissue of bucks aged $1-2$ and $3-$ 5 years compared to similar ones from the southern part. The concentration of $\mathrm{Mg}$ in the osseous tissue of bucks aged 3-5 and 6-9 years was significantly lower compared to individuals from the south. The results of the own studies showed significant differences in the abundance of the blood serum and the osseous tissue of young lambs in examined macroelements according to the area of Western Pomerania region. One may not exclude that the source of that variation is geological substrate of agrocenoses, being a food base of domestic ruminants. Higher concentration of calcium in the mandibular osseous tissue of bucks from the north compared to animals from the south confirms the fact of significant effect of the natural intensive light with limited abundance of substrate in that element on its concentration in organism. On the other hand, its lower concentration in the osseous tissue of lambs from that area points to the necessity of supplementing their dams in that element during pregnancy. These results prove simultaneously the food selectivity of roe deer and their ability to unconstrained supplementation of possible deficiencies, which may serve as a recommendation for ecological agriculture.
\end{abstract}

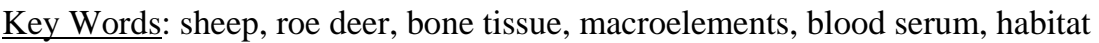

\section{Zusammenfassung}

Titel der Arbeit: Die Konzentration von Makroelementen im Knochengewebe von Lämmern und Rehböcken, untersucht in der Nord- und Südregion Westpommerns in Polen

An Populationen aus der Nord- und Südregion Westpommerns wurden der Gehalt an $\mathrm{Na}, \mathrm{K}, \mathrm{Ca} \mathrm{P}_{\text {anorg. }}$ und $\mathrm{Mg}$ im Blutserum von Lämmern mit dem Gehalt dieser Makroelemente im Knochengewebe verglichen. Knochengewebeanalysen erfolgten am 4. und 5. Schwanzwirbel der Lämmer bzw. Kieferknochen von Rehböcken. Insgesamt 99 Lämmer beiderlei Geschlechts der Rasse Polnisches Merinoschaf im Alter von 14 Tagen ( \pm 2 Tage) und Knochengewebe von 62 Rehböcken einer ökologischen Feldpopulation konnten einbezogen werden. 50 Lämmer mit einem Durchschnittsgewicht von 7,26 $\pm 1,49 \mathrm{~kg}$ stammten aus einem Betrieb im Ostseegürtel Westpommerns ( $53^{0} 59^{\prime} \mathrm{N}$; $\left.15^{\circ} 18^{\prime} \mathrm{E}\right)$ und 49 Lämmer mit einem Durchschnittsgewicht von 7,64 $\pm 1,87 \mathrm{~kg}$ stammten aus einem Gebiet etwa $130 \mathrm{~km}$ südlich entfernt $\left(53^{0} 25^{\prime} \mathrm{N} ; 14^{0} 81^{\prime} \mathrm{N}\right)$. Es wurde eine höhere 
Konzentration von $\mathrm{K}(\mathrm{P} \leq 0,05)$, $\mathrm{Ca}, \mathrm{P}_{\text {anorg. }}$ und $\mathrm{Mg}(\mathrm{P} \leq 0,01)$ sowie niedrigere Konzentration von $\mathrm{Na}(\mathrm{P} \leq 0,05)$ im Blutserum der Lämmer aus dem Norden festgestellt. Das Knochengewebe aus den Schwanzwirbeln dieser Lämmer hatte einen signifikant $(\mathrm{P} \leq 0.01)$ geringeren Gehalt an $\mathrm{Na}, \mathrm{Ca}, \mathrm{P}_{\text {anorg. }}$ und $\mathrm{Mg}$ sowie einen größeren $\mathrm{K}$ Gehalt $(\mathrm{P} \leq 0.01)$ im Vergleich zu den Lämmern aus dem Süden. Das Alter der Rehböcke stellte keine Varianzquelle für den Gehalt an untersuchten Makroelementen im Knochengewebe ihrer Kiefer dar. Im Knochengewebe aus den Kiefern der Rehböcke im Alter von 1-2 und 3-4 Jahre wurde ein höherer (P $\leq 0.01)$ Ca-Gehalt im Vergleich mit dem analogen Tieren aus dem Süden festgestellt. Im Knochengewebe der Rehböcke im Alter von 3-5 und 6-9 Jahre aus dem Norden war der Mg-Gehalt signifikant niedriger als bei den Tieren aus dem Süden. Die Untersuchungen zeigten eine signifikante Differenzierung des Makroelementegehaltes im Blutserum und Knochengewebe der Junglämmer je nach der Region. Die höhere Ca-Konzentration im Knochengewebe aus den Kiefern von Rehböcken aus dem Norden im Vergleich mit den Tieren aus dem Süden bestätigt die Tatsache, dass die intensive natürliche Beleuchtung, bei geringerem Ca-Gehalt im Boden seine Konzentration im Organismus beeinflusst. Die niedrigere Ca-Konzentration im Knochengewebe der Lämmer aus dieser Region weist auf die Notwendigkeit der Zugabe dieses Makroelementes bei den tragenden Muttertieren hin. Die Ergebnisse weisen gleichzeitig nach, dass Rehe durch freie Nahrungswahl die Fähigkeit besitzen, einen Mangel zu ergänzen, was als Empfehlung für die ökologische Landwirtschaft dienen kann.

Schlüsselwörter: Schafe, Rehe, Knochengewebe, Makroelemente, Boden, Umwelt

\section{Introduction}

The previous studies (BARANOWSKI, 2002) showed differences in the concentration of macroelements in the blood serum and the osseous tissue of caudal vertebrae in lambs of five breeds, the genotype of which and the utility type related to it were admitted to be the main reason. At the same time it was noticed that the differences observed might be conditioned by a geochemical factor, which points to a substantial influence of breeding environment - a soil, on the organisms of these lambs in the prenatal period, as well as on individual physiological reactions of young organisms adapting to postnatal environment in the first days of their lifes.

The studies, the results of which are presented now, were induced by a particular location of Western Pomerania. In its costal zone, included according to the geological nomenclature to Pomeranian proglacial stream valley, the bottom is sandy and sandygravelly, and in the part of the Gryfice Plain occur outcrops of Jurassic limestones, directly underneath a thin layer of post-glacial deposits. To the south spreads the Pyrzyce Lowland that is related, in respect of its genesis, to the Pyrzyce pleistocene marginal water lake, which contributed to the sedimentation of water-transported material. Due to climatic changes and water-level lowering, showed here deposits of light loams, clays, dusty and carbonate formations, and other ones, being a valuable soil builder material (BOROWIEC, 1960; 1961).

In this area occur three basic soil types, of which the Pyrzyce black-earths are the most fertile soils in Western Pomerania. These soils are typified by a high content of humus and large abundance of nutrients. Calcium carbonate found in deeper layers makes the soil reaction to be neutral or alcaline (NOWAK et al., 2001). The interest in these soils results also from the occurrence of relicts of steppe vegetation (annual precipitation quota does not exceed $500 \mathrm{~mm}$ sometimes) and the necessity of limiting farm production within the protection zone of Miedwie Lake due to Szczecin drinking water intake situated here.

In connection with the above, the study goal was to compare the concentration of macroelements ( $\mathrm{Na}, \mathrm{K}, \mathrm{Ca}, \mathrm{P}_{\mathrm{ng}}$ and $\mathrm{Mg}$ ) in the blood serum of lambs coming from the northern and the southern region of Western Pomerania, as well as to compare the concentration of these elements in the osseous tissue of caudal vertebrae in sheep 
lambs and of mandible in roe deer bucks populating areas of the same agrocenoses cultivated fields and meadows.

\section{Material and methods}

The studies were carried out in the same year on the blood serum and the osseous tissue of the 4th and 5th caudal vertebrae of 99-days-old Polish Merino lambs $( \pm 2$ days) of both sex and on the mandibular osseous tissue of 62 roe deer bucks (Capreolus capreolus) of an "ecological field population".

The origin of lambs was documentary evidenced and their physical traits were equalized to a great extent. Only lambs with the erythrocyte potassium concentration lower than $27 \mathrm{mmol} / \mathrm{l}$ (BARANOWSKI, 1998) were selected for the study. Fifty lambs with the average body weight of $7.26 \mathrm{~kg} \pm 1.49$ came from a fold in the coastal zone of the Western Pomeranian Province (53 $59^{\prime} \mathrm{N}$; $15^{\circ} 18^{\prime} \mathrm{E}$ ), and 49 lambs with the average body weight of $7.64 \mathrm{~kg} \pm 1.87$ from an area far removed by approximately $130 \mathrm{~km}$ to the south $\left(53^{\circ} 25^{\prime} \mathrm{N} ; 14^{\circ} 81^{\prime} \mathrm{E}\right)$. Lamb dams spent the time preceeding the mating on pasture feeding. In the breeding and gestation periods the ewes stayed in livestock buildings with unrestricted yard access. The ewes of both flocks were mated after September 21 (92 days after summer solstice).

The feeding of dams was similar and based on the farm fodder. The feeding ration consisted of green pasture, meadow hay, fodder beets, carrots, maize and sugar beet leaves silage, spring and winter crops straw, and oat grain and lupine beans, 0.20 $0.25 \mathrm{~kg}$ per each adult ewe daily. When planning the experiment lay-out in the period preceeding the mating it was set forth that the feeding principles for sheep in both flocks were the same and based on Animal Husbandry Institute's Livestock Feeding Standards (RYŚ, 1981). The amount of dry matter, oat units and total digestible protein in a ration was modified solely considering the body weight of dams before the mating, average fecundity of flock in the previous reproductive period and the foetus growth and development period. Up to collecting the study material on the 14th day of life, lambs were fed with dams' milk only. The study material was not collected from lambs, for which artificial emergency feeding was applied or with diarrhoea symptoms.

The mandibular bones of roe deer bucks were collected during the evaluation of hunting trophies. The age of bucks was estimated by the Regional Commission for Hunting Trophies Evaluation members, and the shooting area was declared by hunters. When estimating the age of bucks, the colour of dentine on the occlusal surface of molars was taken into account (REICK, 1970). The mandibles used for age estimation were boiled-out, but not exposed to whitening agents, which could have change dentine colouration. The hunters gave times and stands, where roe deer bucks were shot. The atterntion was paid the collected mandibles came from animals with peculiarly light coloured antlers, which clearly pointed out to field bucks continually exposed to sunbeams.

In total, 239 complete mandibles were collected from bucks, 170 of which from the region of costal zone in the north and 69 from the southern region. For the analysis of osseous tissue mineral composition were used only mandibles from the bucks shot in biotopes located in the close vicinity of cultivated fields belonging to farms with sheep partcicpating in the experiment. For the analysis, 36 samples from the northern region 
and 26 samples from the southern one were used. Additionally, the collected material of 62 mandibles was divided into age groups: $1-2$ years, $3-5$ years, and $6-9$ years. After extracting the premolars and molars from the alveoli of left mandibular bone, a fragment of molar part (pars molaris) of the mandible shaft was cut out, dessicated to solid mass and incinerated. From the curtailed lamb tails the 4th and the 5th caudal vertebrae were obtained. After cleaning the vertebrae from soft tissues, they were stored at $-25^{\circ} \mathrm{C}$ until analysed. On the day of curtailing lamb tails, blood samples were aslso collected from them, which were centrifuged in the laboratory over 20 minutes at $3500 \mathrm{rpm}$. In the blood serum was determined the concentration of sodium, potassium and calcium with flame photometry method, of inorganic phosphorus with the method of Fiske-Subbarow, and of magnesium with atomic absorpion spectrophotometry.

The analytic procedure in respect of the caudal vertebrae of lambs and mandibular osseous tissue of bucks was similar. The concentration of macroelements: sodium, potassium, calcium, magnesium and inorganic phosphorus, was determined after dessicating the material in porcelain melting pots at $105^{\circ} \mathrm{C}$ to solid mass (Table 1 ) and its incineration at $600^{\circ} \mathrm{C}$. Thereafter the following scheme was used: (1) $10 \mathrm{ml}$ of distilled water $+1 \mathrm{ml}$ of concentrated $\mathrm{HCl}$ was added to the melting pots which was next placed in a sand bath of $600^{\circ} \mathrm{C}$ and its content was brought to the boiling point (total dissolution of ash); (2) after cooling the melting pot content was filtered into a $100 \mathrm{ml}$ measuring flask, the pot and the filter being flushed with distilled water several times. Next, the filter was placed in the pot and charred in a sand bath, thereafter being incinerated in a furnace at $600^{\circ} \mathrm{C}$. The ash from the pot after dissolution $\left(5 \mathrm{ml} \mathrm{H}_{2} \mathrm{O}\right.$ and 3 drops of concentrated $\mathrm{HCl}$ ) was brought to the boiling point, and then, after cooling, transferred quantitatively to a $100 \mathrm{ml}$ measuring flask. The flask content was made up with destilled water to $100 \mathrm{ml}$. The solution prepared that way was ready for further assays that were done as in the analysing serum macroelements composition. The assaying of mineral composition of the blood serum and the osseous tissue of lamb caudal vertebrae and of buck mandibles was carried out at the laboratory of the Department of Animal Physiology, Faculty of Biotechnology and Animal Breeding, Agricultural University of Szczecin.

\section{Table 1}

Dry weight of osseus tissue 4 and 5 caudal vertebrae of lambs of Polish Merino and of mandibular bone in roe deer (pars moralis) (Trockenmasse des Knochengewebes des 4. und 5. Schwanzwirbels von Lämmern der Rasse Polnisches Merinoschaf sowie eines Teils des Kieferkörpers (pars moralis) von Rehböcken)

\begin{tabular}{|c|c|c|c|}
\hline \multicolumn{3}{|c|}{ Species } & \multirow{2}{*}{$\begin{array}{c}\text { Dry weight (g) } \\
1.591 \pm 0.416 \\
\end{array}$} \\
\hline \multirow{5}{*}{$\begin{array}{c}\text { Nord } \\
\text { area }\end{array}$} & \multicolumn{2}{|c|}{ Lambs, $n=50$} & \\
\hline & \multirow{4}{*}{ Roe deer } & $1-2, n=12$ & $5.097 \pm 0.662$ \\
\hline & & $3-5, n=17$ & $6.062 \pm 0.735$ \\
\hline & & $6-9, n=7$ & $5.598 \pm 0.828$ \\
\hline & & Total, $\mathrm{n}=36$ & 203.416 \\
\hline \multirow{5}{*}{ South area } & \multicolumn{2}{|c|}{ Lambs, $n=49$} & $0.498 \pm 0.172$ \\
\hline & \multirow{4}{*}{ Roe deer } & $1-2, n=10$ & $3.940 \pm 0.767$ \\
\hline & & $3-5, n=10$ & $5.351 \pm 0.746$ \\
\hline & & $6-9, n=6$ & $5.525 \pm 0.482$ \\
\hline & & Total, $n=26$ & 126.063 \\
\hline
\end{tabular}

The findings of the own studies are given in method units of SI units system. Since the age of examined lambs’ parents, dams’ body weight prior to the mating, lamb sex and 
number in a litter, of which they came, were not a source of variation, one-way analysis of variance with Sheffe's test was used to determine the differences between lamb groups. The same statistics was applied for buck groups examined. The coefficients of linear correlation were determined according to Pearson using a Statistica 5.0 software package.

\section{Results}

The obtained results for sodium, potassium, calcium, inorganic phosphorus and magnesium concentrations in the blood serum and the osseous tissue of sheep lambs (Ovis aries) and the concentration of these elements in the osseous tissue of mandibles of the roe deer bucks (Capreolus capreolus) are presented in Table 2.

Table 2

The content of $\mathrm{Na}, \mathrm{K}, \mathrm{Ca}, \mathrm{P}_{\text {inorg. }}, \mathrm{Mg}$ in serum of lambs and osseous tissue (mmol/l in $1 \mathrm{~g}$ dry weight) of theirs caudal vertebrae and the content of this macroelements in mandibular bone in roe deer ( $\mathrm{Na}, \mathrm{K}, \mathrm{Ca}, \mathrm{P}_{\text {anorg. }}, \mathrm{Mg}$ Gehalt im Blutserum und Knochengewebe ihrer Schwanzwirbel sowie Gehalt an diesen Elementen im Knochengewebe des Kiefers von Rehböcken)

\begin{tabular}{|c|c|c|c|c|c|c|c|c|c|c|c|c|}
\hline \multirow{4}{*}{\multicolumn{2}{|c|}{ Species }} & \multicolumn{10}{|c|}{$\begin{array}{c}\text { Macroelements } \\
\text { (serum in } \mathrm{mmol} / \mathrm{l} \text { and in } \mathrm{mmol} / \mathrm{l} \text { in } 1 \mathrm{~g} \text { dry weight of bone tissue) }\end{array}$} & \multirow{3}{*}{$\begin{array}{c}\text { Ash (g) } \\
\text { Mean SD }\end{array}$} \\
\hline & & \multicolumn{2}{|c|}{$\mathrm{Na}$} & \multicolumn{2}{|c|}{$\mathrm{K}$} & \multicolumn{2}{|c|}{$\mathrm{Ca}$} & \multicolumn{2}{|c|}{$\mathrm{P}_{\text {ing. }}$} & \multicolumn{2}{|c|}{$\mathrm{Mg}$} & \\
\hline & & Mean & SD & Mean & SD & Mean & SD & Mean & SD & Mean & SD & \\
\hline & & \multicolumn{10}{|c|}{ Nord are } & \\
\hline \multirow{2}{*}{$\begin{array}{c}\text { Lambs } \\
n=50\end{array}$} & Serum & $142.08^{\mathrm{a}}$ & 10.11 & $4.96^{\mathrm{a}}$ & 0.47 & $2.42^{\mathrm{A}}$ & 0.27 & $3.36^{\mathrm{A}}$ & 0.25 & $1.25^{\mathrm{A}}$ & 0.09 & 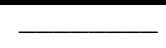 \\
\hline & $\begin{array}{l}\text { Bone } \\
\text { tissue }\end{array}$ & $2.74^{\mathrm{A}}$ & 0.37 & $1.29^{\mathrm{A}}$ & 0.23 & $9.51^{\mathrm{B}}$ & 1.78 & $9.70^{\mathrm{B}}$ & 1.76 & $0.84^{\mathrm{B}}$ & 0.11 & $0.26 \quad 0.03$ \\
\hline \multirow{4}{*}{$\begin{array}{c}\text { Roe } \\
\text { deer } \\
\text { (bone } \\
\text { tissue) }\end{array}$} & $1-2, n=12$ & 2.53 & 0.60 & 0.039 & 0.02 & $63.21^{\mathrm{A}}$ & 6,51 & 47.81 & 12.85 & 19.70 & 1.93 & $0.36^{\mathrm{a}} \quad 0.02$ \\
\hline & $3-5, n=17$ & 2.51 & 0.55 & 0.037 & 0.01 & $61.72^{\mathrm{A}}$ & 8.56 & 43.83 & 10.03 & $17.61^{\mathrm{d}}$ & 1.28 & $\begin{array}{ll}0.34 & 0.02 \\
\end{array}$ \\
\hline & $6-9, n=7$ & 2.55 & 0.25 & 0.030 & 0,01 & 64.74 & 9.09 & 42.84 & 22.33 & $16.95^{\mathrm{E}}$ & 1.79 & $0.34 \quad 0.03$ \\
\hline & $\begin{array}{l}\text { Total, } \\
\mathrm{n}=36\end{array}$ & 2.53 & 0.46 & 0.035 & 0.01 & 63.22 & 8.05 & 44.83 & 15.07 & 18.09 & 1.66 & $0.34^{\mathrm{a}} 0.02$ \\
\hline
\end{tabular}

South are

\begin{tabular}{c|c|cc|cc|cc|cc|cc|cc}
\hline \multirow{2}{*}{$\begin{array}{c}\text { Lambs } \\
\mathrm{n}=49\end{array}$} & Serum & $148.90^{\mathrm{a}}$ & 9.30 & $4.91^{\mathrm{a}}$ & 0.38 & $2.33^{\mathrm{A}}$ & 0.13 & $3.12^{\mathrm{A}}$ & 0.42 & $1.02^{\mathrm{A}}$ & 0.14 & $\bar{l}$ \\
\cline { 2 - 13 } & $\begin{array}{c}\text { Bone } \\
\text { tissue }\end{array}$ & $3.31^{\mathrm{A}}$ & 0.68 & $0.90^{\mathrm{A}}$ & 0.28 & $13.80^{\mathrm{B}}$ & 3.32 & $16.70^{\mathrm{B}}$ & 2.31 & $0.98^{\mathrm{B}}$ & 0.18 & 0.26 & 0.04 \\
\hline \multirow{2}{*}{$\begin{array}{c}\text { Roe } \\
\text { deer } \\
\text { (bone } \\
\text { tissue) }\end{array}$} & $1-2, \mathrm{n}=10$ & 2.46 & 0.17 & 0.060 & 0.03 & $49.94^{\mathrm{A}}$ & 8.65 & 40.74 & 6.40 & 19.51 & 1.61 & $0.39^{\mathrm{a}}$ & 0.04 \\
\cline { 2 - 13 } & $3-5, \mathrm{n}=10$ & 2.55 & 0.24 & 0.033 & 0.01 & $48.13^{\mathrm{A}}$ & 3.89 & 36.99 & 3.88 & $18.89^{\mathrm{d}}$ & 1.31 & 0.35 & 0.03 \\
\cline { 2 - 11 } & $\begin{array}{c}\text { Total, } \\
\mathrm{n}=26\end{array}$ & 2.92 & 0.47 & 0.042 & 0.02 & 57.73 & 14.77 & 36.90 & 7.82 & $21.47^{\mathrm{E}}$ & 3.00 & 0.33 & 0.02 \\
\hline
\end{tabular}

Explanation: means bearing the same superscripts in column are different at - capital letters $\mathrm{P} \leq 0.01$; small letters $\mathrm{P} \leq 0.05$.

Lamb blood serum. Lower serum sodium concentration, by $6.82 \mathrm{mmol} / \mathrm{l}$, was recorded in lambs coming from the northern area compared to that in lambs from the south $(\mathrm{P} \leq 0.05)$, contrary to potassium content $(\mathrm{P} \leq 0.05)$. In the blood serum of lambs from the north the concentration of calcium, inorganic phosphorus and magnesium was significantly higher $(\mathrm{P} \leq 0.01)$ than in that of lambs from the south (Table 2$)$.

Lamb osseous tissue. The highest sodium concentration $(3.31 \mathrm{mmol} / \mathrm{l} \pm 0.68$ in $1 \mathrm{~g}$ d.w.) was recorded in the osseous tissue of lambs coming from the southern area of the 
Province, while the lowest $(2.74 \mathrm{mmol} / \mathrm{l} \pm 0.37$ in $1 \mathrm{~g}$ d.w.) in those from the north $(\mathrm{P} \leq 0.01)$. Alike serum potassium concentration, the concentration of that element in the osseous tissue of lambs from the north was higher $(\mathrm{P} \leq 0.01)$ and exceeded by 0.39 $\mathrm{mmol} / \mathrm{l}$ its concentration in the osseous tissue of caudal vertebrae in lambs from the south.

Calcium and phosphorus concentrations in the osseous tissue of caudal vertebrae in lambs from the north differed significantly $(\mathrm{P} \leq 0.01)$ from those in the osseous tissue of lambs from the southern area. Comparison of calcium concentration in the osseous tissue of caudal vertebrae in lambs from the north to that in blood serum indicated that its lower level in osseous tissue $(9.51 \mathrm{mmol} / \mathrm{l} \pm 1.78$ ) corresponded with its higher concentration in blood serum $(2.42 \mathrm{mmol} / \mathrm{l} \pm 0.27)$, while vice versa in the south - its lower level in blood serum $(2.33 \mathrm{mmol} / \mathrm{l} \pm 0.13)$ conditioned a higher level in osseous tissue $(13.80 \mathrm{mmol} / \mathrm{l} \pm 3.32)$. Similar situation was observed in case of inorganic phosphorus concentration, respectively, 9.70 to $3.36 \mathrm{mmol} / \mathrm{l}$ in the north and 16.70 to $3.12 \mathrm{mmol} / \mathrm{l}$ in the south.

Similar relationship occurred in relation to magnesium concentration - its higher concentration in the blood serum of lambs in the north $(1.25 \mathrm{mmol} / \mathrm{l} \pm 0.09)$ with a lower one in osseous tissue $(0.84 \mathrm{mmol} / \mathrm{l} \pm 0.11)$, and its lower concentration in blood serum in the south $(1.02 \mathrm{mmol} / \mathrm{l} \pm 0.14)$ with a higher one $(\mathrm{P} \leq 0.01)$ in osseous tissue $(0.98$ $\mathrm{mmol} / \mathrm{l} \pm 0.18$ ). The mean ash content obtained from incinerated caudal vertebrae of both lamb groups was the same (Table 2).

Buck mandibular osseous tissue. No significant differences were recorded in the concentration of analysed elements in the osseous tissue of buck mandibles due to the age of shot bucks. There were no differences in sodium and potassium concentrations in that tissue either. However, a mandible mineral composition determining factor, in respect of calcium and magnesium concentrations, was the very Western Pomeranian region. In the material obtained from animals from the northern part of the region a higher calcium concentration $(\mathrm{P} \leq 0.01)$, by $11.29 \mathrm{mmol} / \mathrm{l}$ on the average, was recorded than in those from the south. The allowance for age in the analysis showed in that group of bucks that the youngest animals, i.e. aged 1 to 2 years, are typified by a slightly higher concentration of that element, by $1.48 \mathrm{mmol} / \mathrm{l}(2.35 \%)$, when compared to animals aged 3 to 5 years. Six-years-old animals and older shot in the north had a higher concentration of calcium, by $3.01 \mathrm{mmol} / \mathrm{l}$ (4.66\%), when compared to the concentration of that element in the osseous tissue of bucks aged at the age of $3-5$ years.

In the osseous tissue of animals from the southern area, the difference in calcium concentration between 1-2-years-old bucks and 3-5-years-old ones amounted to $1.81 \mathrm{mmol} / \mathrm{l}$ (3.62\%). Six-years-old bucks and older from that area (with mean $\mathrm{Ca}$ concentration of $57.73 \mathrm{mmol} / \mathrm{l} \pm 14.77$ ) had a higher concentration of that element, by $9.60 \mathrm{mmol} / \mathrm{l}$, when compared to 3-5-years-old bucks (with mean Ca concentration of $48.13 \mathrm{mmol} / \mathrm{l} \pm 3.89)$ than those shot in the northern area $(64.74 \mathrm{mmol} / \mathrm{l} \pm 9.09$ and $61.72 \mathrm{mmol} / \mathrm{l} \pm 8.56$ ) with a lower mean concentration by $11.29 \mathrm{mmol} / \mathrm{l}$.

Magnesium concentration in the osseous tissue of the youngest bucks shot in both areas was similar $(19.70 \mathrm{mmol} / \mathrm{l}$ and $19.51 \mathrm{mmol} / \mathrm{l})$. There were differences $(\mathrm{P} \leq 0.05)$ in the concentration of that element between older animals - 3-5-years-old and 6-9years-old ones. The 3-5-years-old animals from the north were typified by a lower 
magnesium concentration when compared to such bucks from the south by $1.28 \mathrm{mmol} / \mathrm{l}(\mathrm{P} \leq 0.05)$. On the other hand, magnesium concentration in the osseous tissue of mandible $(21.48 \mathrm{mmol} / \mathrm{l})$ in the oldest bucks from the south exceeded by $4.59 \mathrm{mmol} / \mathrm{l}$ (over $27 \%$ ) the value recorded in animals from the north $(\mathrm{P} \leq 0.01)$.

The highest ash concentration was recorde in the osseous tissue of the youngest animals, and the value determined for bucks from the north was by $0.034 \mathrm{~g}$ lower $(\mathrm{P} \leq 0.05)$ than that for those from the south.

\section{Discussion}

Animals used in the own studies come from areas, which differ fundamentally in respect of agrotechnical treatments applied. This is due to that that light soils in the north area of the region contain in the topsoil 1.3 to $1.5 \%$ humus, their reaction is slightly acid, and $\mathrm{P}, \mathrm{K}$ and $\mathrm{Mg}$ are considered to be of low-availability. In the south, in the vicinity of Miedwie Lake, the topsoil has $1.8-2.0 \%$ humus, and $\mathrm{P}, \mathrm{K}$ and $\mathrm{Mg}$ are considered to be of medium-availability. Due to calcium carbonate found in deeper layers, the soil is of neutral reaction. The rot layer in the soil profile occurs down to $40-50 \mathrm{~cm}$ and is bedded with the lime containing $90 \% \mathrm{CaCO}_{3}$ on the average. The soil reaction in top layer $(0-25 \mathrm{~cm})$ ranges $5.6 \mathrm{pH}$ to $6.9 \mathrm{pH}$ (CYRAN, 1994; KOSZAŃSKI et al., 1994).

The differences in sodium concentration in the blood serum $(\mathrm{P} \leq 0.05)$ and osseous tissue $(\mathrm{P} \leq 0.01)$ of lambs coming from the two examined areas were likely induced by the adaptation of dams of these animals to specific environmental conditions (PASTRANA et al., 1991). In the light of the reference values operative in Poland (WINNICKA, 1997) for sheep (147.8 - $160.9 \mathrm{mmol} / \mathrm{l})$, sodium concentration in the blood serum of lambs from the north $(142.08 \mathrm{mmol} / \mathrm{l} \pm 10.11)$ should be considered to be very low. At the same time, a high potassium concentration, though contained within the standard range $(4.1-5.1 \mathrm{mmol} / \mathrm{l})$, was recorded in the blood serum of these lambs. It is possible that large amount of sodium compounds in plants from those soils and high concentration of intracellular potassium in plants cause increased excretion of sodium and its decreased concentration in blood serum. Despite the fact that animals stay in environment with high availability of sodium, in consequence they do not have to use it sparingly, a certain amount of sodium in direct metabolic processes at the cellular level is supplemented with potassium, which was demonstrated in sheep (EANGLISH, 1967) and goats (BARANOWSKI, 1972).

As it was stated previously (KLATA, 2000), high concentration of sodium in the soil and plants in the coastal region may facilitate the assimilation of magnesium by organism, even with its low level in sandy soils (LEONTONOWICZ et al., 1994). Therefore, it is likely that magnesium concentration in the blood serum of lambs from the north was higher $(\mathrm{P} \leq 0.01)$. The value of the coefficient of correlation for sodium and magnesium concentrations in osseous tissue was $r=0.24$. It is also symptomatic that the value of the coefficient of correlation of the both traits for animals from the south amounted to $\mathrm{r}=0.21$.

The magnesium content in plants is also influenced by soil humidity, its temperature, insulation time and soil oxygen content (NOWAK, 1979). In the coastal zone the precipitation quota considerably exceeds the values recorded in the vicinity of Miedwie Lake $(500 \mathrm{~mm})$. It results from the studies on the influence of intensive 
agrotechnique that with good soil humidity a decrease of magnesium content in plants may occur (KOSZAŃSKI et al., 1994). Low magnesium concentration in the osseous tissue of lambs from the north might have resulted from the feeding of pregnant dams with maize silage in winter. This fodder contains low amounts of magnesium (RYŚ, 1981), and additionally the same for sandy and sandy gravelly soils in the area with high precipitation intensifies deficiency situation. Intermediate soils are more abundant in magnesium and the plants cultivated on them, in particular beets and wheat, as well as maize, contain more magnesium (KOSZAŃSKI et al., 1994). Total magnesium content in humus layers ranges 50 to $254.2 \mathrm{mg} / 100 \mathrm{~g}$, accordingly to the amount of floating elements (5 to 28\%) contained in a given soil type. Mineral material of light loamy soils (25\% floating elements) contains in total five times more magnesium in comparison to $5 \%$ in mellow sandy soil (BŁASZCZYK, 1997).

Studies made on nursing dams of Mutton Black Head and Romney Marsh sheep (BARANOWSKI et al., 1998) as well as on pregnant ewes of Pomeranian form of the Polish long-wool sheep (BARANOWSKI and KMIEĆ, 1997) in the same region showed that magnesium concentration in sheep in the 6th week before parturition and in the second week of lactation was close to a lower limit of physiological standard $0.82 \mathrm{mmol} / \mathrm{l}$ (WINNICKA, 1997). This is followed also by metabolic consequences in organism of dams (BARANOWSKI and GRZESIAK, 2001). High magnesium concentration in the blood serum of suckling lambs is caused by its high content in milk of dams, which exceeds over six times its serum concentration (JELINEK et al., 1996).

High magnesium concentration in the osseous tissue of the mandibular bone of the 35-years-old and the oldest bucks coming from the southern area of the region might have been due to the penetration of these animals into various biotopes, this way supplementing the magnesium deficiency. The examination of mineral composition of herbs and meadow weeds showed that in unattended meadows, being probably a feeding ground for roe deers, the magnesium content ranges 2179 to $9187 \mathrm{ppm}$. Wellmaneged meadows, frequently located in the vicinity of human colonies and less visited by roe deers, have 1772 to $5710 \mathrm{ppm}$ magnesium in herbs and grasses (CYRAN, 1994).

The following values of the coefficient of correlation were calculated for sodium and magnesium concentrations in the osseous tissue of the mandibular bone of bucks from coastal agrocenoses: for $1-2$-years-old $r=-0.32$, for 3-5-years-old $r=0.39$, for 6 9 -years-old $r=0.08$. For bucks from the south the $r_{x y}$ value was as follows: $0.47,-0.26$ and -0.27 , respectively.

The increasing of soil humidity is favourable for calcium assimilation by plants. High concentration of this element in the osseous tissue of the mandibular bone of bucks from the northern agrocenoses might have been caused by higher humidity of the environemnt and by significant insolation of coastal areas in summer. In green fodder, being the main fodder in summer feeding of livestock and wild animals, vitamin $\mathrm{D}$ is missing. Green fodder has only a certain amount of ergosterol. This provitamin can not be used by animals, as it is not absorbed by their alimentary tract. It is transformed into vitamin $\mathrm{D}_{2}$ only affected by the energy of UV radiation photons. It seems that the presented results of the own studies corroborate the opinion that the decrease of sodium content in blood serum is accompanied by the increased calcium content, and vice versa (KOKOT, 1986). 
It was found in the own studies that phosphorus concentration in the osseous tissue of the mandibular bone of the 1-2-years-old bucks shot in the two examined areas of the province was the highest (without statistical confirmation). In the material obtained from the next generations of bucks lower values, by $10 \%$, were recorded. It resulted from the data obtained in the own studies that the estimated Ca:P ratio was unfavourable, both in lamb blood serum and osseous tissue. It was 0.7:1 in the blood serum and 0.9:1 in the osseous tissue of caudal vertebrae of lambs. In roe deer it was as follows: 1.3:1 in the mandibular osseous tissue of the $1-2$-years-old bucks from the costal zone, 1.4:1 in the 3-5-years-old bucks, and 1.5:1 in the 6-9-years-old ones. This ratio in the mandibular osseous tissue of bucks from the south was as follows: $1.2: 1,1.3: 1$ and $1.6: 1$, respectively. The ratio of magnesium and these elements in the mandibular osseous tissue of bucks shot in the coastal zone was as follows: 0.3:1:0.8 in the 1-2-years-old bucks, 0.3:1:0.7 in the 3-5-years-old bucks, and $0.3: 1: 0.7$ in the 6-9-years-old ones. In the mandibular osseous tissue of bucks from the south these values were as follows: 0.4:1:0.8, 0.4:1:0.8 and 0.4:1:0.6, respectively.

One can not exclude that lower concentration of inorganic phosphorus in the mandibular osseous tissue of bucks from the south may reflect a limited supply of liquid manure introduced into cultivated environment in that area.

The presented results of the own studies showed significant differences in the abundance of the blood serum and the osseous tissue of young lambs in examined macroelements according to the area of Western Pomerania region. One may not exclude that the source of that variation is geological substrate of agrocenoses, being a food base of domestic ruminants. Higher concentration of calcium in the mandibular osseous tissue of bucks from the north compared to animals from the south confirms the fact of significant effect of the natural intensive light with limited abundance of substrate in that element on its concentration in organism. On the other hand, its lower concentration in the osseous tissue of lambs from that area points to the necessity of supplementing their dams in that element during pregnancy. These results prove simultaneously the food selectivity of roe deer and their ability to unconstrained supplementation of possible deficiencies, which may serve as a recommendation for ecological agriculture.

\section{References}

BARANOWSKI, P.; KMIEĆ, M.:

Normal values of selected blood indicators in Polish long-wool sheep (In Polish). Życie Weterynaryjne 9 (1997), , 355-357

BARANOWSKI, P.,

Selected biochemical indicators of lamb blood serum in relation to the erythrocyte potassium level. Animal Science Papers and Reports 16 (1998) 1, 25-33

BARANOWSKI, P.; BARANOW-BARANOWSKI ST.; KLATA, W.; KMIEĆ, M.:

The effect of Polfamix "O" and Vitazol $\mathrm{AD}_{3} \mathrm{E}$ preparations on $\mathrm{Ca}, \mathrm{P}$ and $\mathrm{Mg}$ contents in blood serum of sheep in the second week of lactation (In Polish). Życie Weterynaryjne 11 (1998) , 431-433

BARANOWSKI, P.; GRZESIAK, W., Seasonal changes in some serum indicators in pregnant and barren leine sheep. Folia Veterinaria 45 (2001) 3, 122-128

BARANOWSKI, P.,

Genetic and environmental factors of macroelements concentration in blood serum and osseous tissue of lambs in north-west Poland. Arch. Tierz., Dummerstorf 45 (2002) 6, 565-574 


\section{BARANOWSKI, ST.:}

The influence of sodium insufficiency in fodder on the functioning of kidneys and the lactic gland (In Polish). Rozpr., AR Szczecin 29 (1972), 3-32

BOROWIEC, S.:

Genesis of soils developed from the Pyrzyce formations, a pleistocene marginal lake, in the light of hitherto existing data (In Polish). Zesz. Nauk. WSR Szczecin 4 (1960), 3-37

BOROWIEC, S.:

Differention of conditions in agricultural area of Pleistocene water on background of Pyrzyce administration district (In Polish). Rocz. Nauk Rol. 84 (1961), 614-630

BŁASZCZYK, W.H.:

Influence of environment factors on the content of magnesium in westren Pomerania soils (In Polish). Biuletyn Magnezologiczny 2 (1997), 98-105

CYRAN, A.:

The content of certain macroelements in herbs and weeds extraneous in a negleted meadow and well managed (In Polish). Biuletyn Magnezologiczny 4 (1994), 44-47

EANGLISH, P.B.:

A study of water and electrolyte metabolism in sheep. Part III. Sodium depletion, Br. Vet. J., 3 (1967), 111-117

JELINEK, P.; GAJDUSEK, S.; ILLEK, J.:

Relationship between selected indicators of milk and blood in sheep. Small Rum. Res., 20 (1996) 1, 5357

KOKOT, F.:

Water-electrolyte and acidic-alkaline balance in physiological and pathological states (In Polish). PZWL, Warszawa, 1981

KOSZANSSI, Z.; PODSIADŁO, C.; ROY, M.:

Influence of intensive agrotechnique on yield and magnesium content in soil and crop (In Polish). Biuletyn Magnezologiczny 4 (1994), 88-92

LEONTONOWICZ, H.; GRALAK, M.; LEONTONOWICZ, M.; LEŚNIEWSKA, V.:

The effect of $\mathrm{Ca}$ and $\mathrm{Mg}$ surplus in diet on digestibility, rumen protein synthesis and mineral components balance in growing sheep (In Polish). Konf. Nauk. Związki mineralne w żywieniu zwierząt, Poznań 8-9. IX. (1994), 217-220

NOWAK, J.; NIEDŹWIECKI, E.; NOWAK, A.; ŚNIEG, B.:

Biological properties of arable soils of the Pyrzyce lowland during vegetation period (In Polish). Folia Univ. Agric. Stetin. 221 Agricultura 88 (2001), 183-200

NOWAK, M.:

The content of mineral components and some trace elements in meadow-pasture overgrowth. (In Polish). Zesz. Probl. Post. Nauk Rol, 221 (1979), 161-168

PASTRANA, R.; MCDOWELL L.R.; CONRAD J.H.; WILKINSON N.S.:

Macromineral status of sheep in the Paramo region of Columbia. Small Ruminant Research 5 (1991), 921

REICK, W.:

Alter und Gebissabnutzung beim Rehwild. Z. Jagdwiss 16 (1970) 1, 1-7

RYŚ, R.,

Feeding standards for livestock (In Polish). PWRiL, Warszawa, 1981

WINNICKA, A.:

Reference values of basic laboratory tests in veterinary medicine (In Polish). Wydawnictwo SGGW, 3115, 1997

ZENKER, H.; HENTSCHEL, G.:

Seasonal differences in course of weather conditions on coast and in depth of country in NRD (In

Polish). Probl. Uzdr. 1-2 (1975), 157-162

Received: 2003-05-23

Accepted: 2004-01-12

Author's address

Doz. Dr. habil. PIOTR BARANOWSKI, MGR INŻ. WIESŁAWA KLATA,

Prof. ZW. Dr. habil. STANISŁAW BARANOW-BARANOWSKI

Laboratory of Ruminants Environment, Department of Ruminants Science, Faculty of Biotechnology and Animal Breeding, Agricultural University of Szczecin

ul. Doktora Judyma 10

71-460 Szczecin

Poland 